Mikko Keskinen

\title{
Ääniteknologiat ja kirjallisuus
}

Ennen kuin Alexander Graham Bell keksi puhelimen vuonna 1876 ja Thomas Alva Edison fonografin vuotta myöhemmin, äänten kuuleminen merkitsi välttämättä sitä, että akustisen informaation lähde oli havainnoijalle läsnä tai ainakin kuulomatkan päässä. ${ }^{1}$ Äänen tallentamisen tai välittämisen teknologioiden puuttuminen merkitsi käytännössä sitä, että 1800-luvun loppupuolelle saakka kuuleminen toi melkein aina mukanaan näkemisen (Gitelman 1999, 26). Inhimillisessä viestinnässä tämä tarkoitti poikkeuksetta, että puhuvan subjektin ääni lankesi yksiin hänen läsnäolonsa kanssa ajallispaikallisesti jaetussa puhetilanteessa. Mutta muuan toinen teknologia, paljon vanhempi kuin puhelin tai fonografi, väitti pystyvänsä tallentamaan kieltä ja saattamaan sen kuuluville - ja jopa manaamaan artikuloijan jollakin tavoin läsnä olevaksi - pitkien matkojen ja ajanjaksojen takaa. Tuo teknologia on nimeltään kirjoitus.

On historiallinen tosiasia, että puhuttu kieli edeltää kirjoitusta sekä ihmiskunnan historiassa että yksilön kehityksessä. Ihmiset puhuivat tuhansia vuosia ennen kuin mitään kirjoitusjärjestelmää puheen tallentamiseksi visuaaliseen muotoon oli keksitty. Samoin nykyajan lapsi alkaa kirjoittaa muutakin kuin yksityisiä raapustelujaan vasta puhuttuaan vuosien ajan. Esihistoriallisina aikoina opittiin kirjoittamaan muistiin arkikielen lisäksi myös erityisen kohosteista sanallista ilmausta, kirjallisuutta kirjaimellisesti avant la lettre. Suullisen "kirjallisuuden" perinne ja siihen liittyvä oraalisen kulttuurin ajatusmalli ovat jatkuneet esihistoriasta 1900- ja 2000-luvuille saakka, vaikkakin vähentyen samassa suhteessa kuin kirjoitus- ja lukutaito ovat yleistyneet. ${ }^{2}$

Kirjoitusjärjestelmät eivät kuitenkaan olleet ainoat tavat tallentaa ja varastoida kielellistä informaatiota. Puhuttu kieli, erityisesti oraalinen "kirjallisuus" - johon kuuluvat kansanrunojen ja -satujen lisäksi sanalaskut ja mietelmät - sisälsi lukuisia muistiteknisiä keinoja, jotka mahdollistivat viestin sisällön siirtämisen sukupolvelta toiselle suhteellisen muuttumattomassa muodossa. Näitä suullisia muistitukia olivat kaavamainen rakenne, toisto, alku- ja loppusointu sekä mitta (Ong 1982, 33-35; Kittler 1990/1985, 206-209). Kun kieli tallennettiin säilyviin materiaaleihin ja kun siitä tuli näin julkisesti luettavaa, kirjallisuuden muistitekniset ominaisuudet kävivät muistamisen kannalta ylimääräisiksi. Vastineeksi muistituet saivat muita tehtäviä. On oletettavaa, että keinot joita käytettiin suullisessa kirjallisuudessa pääasiassa muistamisen takia, muuttuivat poeettisiksi kirjallisuuden kirjoitetussa vaiheessa. Tämä poetisointi ei liittynyt merkityksen 
säilyttämiseen vaan tuottamiseen, päinvastoin kuin oraalisessa kirjallisuudessa. Erityisesti monet äänteelliset kuviot menettivät muistitekniset tehtävänsä ja muuttuivat lähinnä esteettisiksi. Äännekuviot saattoivat lisätä tekstin yhtenäisyyttä, korostaa joitakin puolia, kuulostaa sopu- tai riitasointuiselta ja matkia ulkomaailman ääniä (Hrushovski 1980). Esimerkiksi esseeni toiseksi viimeisessä jaksossa siteerattu Zacharias Topeliuksen runo on helpohko oppia ulkoa säännöllisen mittansa ja äännekuviointinsa takia, mutta molemmat liittyvät olennaisemmin juuri Hrushovskin mainitsemiin tehtäviin.

Luomalla mimeettisen illuusion ihmisen, eläinten, luonnonilmiöiden tai koneiden äänistä kirjoitus näennäisesti ylittää sisäsyntyisen mykkyytensä. Kirjoitus, erityisesti kaunokirjallinen kirjoitus, ikään kuin voi sisältää ja välittää kielen äänteellisyyden lisäksi ainakin osan tekstin ulkopuolisesta äänimaisemasta ja ihmisäänen erityispiirteistä. Kaunokirjallisuuden ja fonografin (ja muiden ääntä tallentavien laitteiden) välillä näyttää siis olevan tietty yhteys. Molemmat tallentavat ja toistavat ääntä. Tämä yhteys ei ole ainoastaan metaforinen, vaan se on piirtynyt syvälle kirjoitus- ja ääniteknologioiden historiaan. Teen esseessäni katsauksen tuon suhteen tärkeimpiin vaiheisiin, teoreettisiin ongelmiin ja mahdollisiin tulevaisuudennäkymiin.

\section{Kuvitelmia tallennetusta äänestä}

Joskus kirjailijat keksivät koneita tai teknologioita, jotka voidaan toteuttaa vasta vuosikymmenten tai -satojen kuluttua. Jules Vernen kuuraketti ja sukellusvene ovat tuttuja esimerkkejä sepitteellisistä keksinnöistä, joiden toteutumista jouduttiin odottamaan pitkä tovi, ja jotkut hänen kojeistaan ovat edelleen olemassa vain fiktiossa. Myös unelma äänen mekaanisesta säilömisestä ja toistamisesta esiintyy monella kirjailijalla vuosisatoja ennen fonografin keksimistä. Vangitun äänen historia on yhtä vanha kuin länsimainen kirjallisuus. ${ }^{3}$

1600-luvun Kiinasta raportoitiin merkillisestä keksinnöstä. Se koostui puisesta lieriöstä, johon puhuja saattoi lausua sanansa, sinetöidä säiliön ja lähettää sen tuhansienkin kilometrien päässä olevalle vastaanottajalle. Kun tämä rikkoi sinetin, puhujan ääniviesti vapautui vankeudestaan kuuluville. Ajatus ääniaaltojen pyydystämisestä säiliöön toistuu myös italialaisen oppineen, Giovanni Battista Portan, kuvauksessa "puhuvasta putkesta" vuodelta 1589 ja saksalaisen historioitsijan, J.J. Becherin, liki sata vuotta myöhemmässä selonteossa "strentofoniumista". Tuo laite muodostui pullosta ja sen sisään asetetusta spiraalimaisesta metallilangasta, jotka yhdessä kykenivät ottamaan kiinni ja säilyttämään puhuttuja sanoja. Äänen pyydystäminen, kuljettaminen ja vapauttaminen eivät toki olleet eurooppalaisten ja kiinalaisten etuoikeus. Anonyymin kirjailijan teos 1630-luvulta, Le courrier véritable, kuvaa Australian aboriginaalien käyttäneen ääniä imeviä pesusieniä, jotka puristettaessa vuodattivat niihin puhutut sanat ilmoille. 
Edellä esittelemäni selostukset ovat tietenkin, "tieteellisestä" ilmiasustaan huolimatta, historiallisia huijauksia. Vaikka ääniaalto on nesteeseen liittyvä metafora, akustista ilmiötä ei voi, yksinkertaisista fysikaalisista syistä, vangita astiaan niin kuin vettä. Väärennetyt kuvaukset kiehtovista keksinnöistä pystyvät kuitenkin sisältämään - tai pikemminkin valuttamaan ulos - toiveen äänen materiaalisesta säilyttämisestä ja toistamisesta. Tuota vielä toteuttamattomissa ollutta unelmaa käsittelivät myös kaunokirjailijat. Nesteeksi ymmärretyn äänen varastointi jäädyttämällä ja toistaminen sulattamalla on topos, joka on johdettavissa antiikkiin saakka. Plutakhoksen Moralia sisältää tarinan puhutuista sanoista, jotka jätyvät talvella ja jotka sulavat keväällä samalla muuttuen uudestaan kuuluviksi. Äänen varastoinnin ja toistamisen tarina on myös merkityksen muodostumisen allegoria, jossa kielellinen informaatio säilyy muuttumattomana, kunnes sitä viipeen jälkeen voidaan työstää. Allegorisesti tarina merkitsee myös sitä, että nuoruudessa kuullut viisaat sanat tallentuvat muistiin ja tulevat ymmärretyiksi vasta vanhuuden päivinä, kypsymisen myötä. (Kahn 2001, 204.)

Tarina jät̆tyneistä äänistä toistuu myös 1500-luvun kansantarinoissa, eräässä paroni Münchausenin seikkailussa, Baldassare Castiglionen Il cortegiano -teoksessa (1528) ja eritoten François Rabelais'n Gargantua et Pantagruel -romaanissa (1532). Rabelais'n tarina kertoo taistelusta, joka käydään niin kylmässä säässä, että kaikki sotaisat äänet jäätyvät ja putoavat maahan. Seuraavana kevāänä nuo jähmettyneet äänet sulavat ja pääsevät yhtä aikaa kuuluville, minkä seurauksena syntyy kakofonia (Kahn 2001, 205). Muuan tätä merkillistä ilmiötä todistava henkilö ehdottaa, että joitakin jäätyneistä sanoista voitaisiin säilöä kauemmaksi aikaa upottamalla ne olkiin ja öljyyn, jolloin luonnonoikku saataisiin hyötykäyttöön. Puheen säilöminen toteutui toisella tekniikalla, mutta yhtä tahraavalla kuin öljy: kirjapainolla. Irtokirjakkeita kutsuttiin 1500-luvulla yleisesti "mustiksi hampaiksi", koska ne olivat kulmikkaita ja musteisia (Kahn 2001, 206). Painokone, joka oli suunniteltu tuottamaan standardoidun mykkää kirjoitusta, oli näin metaforisesti lähellä kielen oraalisuutta.

Vielä kehittyneempi teknologinen innovaatio esitellään Cyrano de Bergeracin romaanissa Histoire comique des états et empires de la lune (1656). Siinä kuuhun matkannut kertoja saa haltuunsa paikallisen kirjan, jonka sivuilla ei ole kirjoitusta vaan mekanismi, joka kaiuttaa kuuluville kunkin luvun sisällön kun sitä koskettaa neulalla. Tämä kuviteltu äänikirja on mekaniikaltaan hätkähdyttävästi varhaisten ääniteknologioiden kaltainen - kaksi vuosisataa ennen fonografin keksimistä. Kuun ihmisten äänikirjalle ja fonografille olivat yhteistä neula, kellon rattaita muistuttava koneisto ja näennäisen tyhjä (tai ainakin lukukelvoton) tallennuspinta.

Fonografia muistuttava tallennus- ja toistoteknologia ei kuitenkaan ollut pelkästään kirjailijoiden villien kuvitelmien tai sattuman oikusta myöhempiä keksintöjä muistuttavien sepitteellisten kojeiden varassa. Ranskalaisrunoilija Charles Cros (1842-1888) 
todella keksi ja suunnitteli periaatteen, jota Thomas Alva Edison kutsui tahollaan fonografiksi (Levin 1995). Kevälllä 1877 Cros esitti Pariisin tiedeakatemialle piirustukset parliofoni-kojeesta. Sen oli märä rakentua vahasylinteristä, johon neula painaisi ääniaaltojen vaikutuksesta jälkiä yhtenäiseksi uraksi; toistoasennossa neula liikkuisi uraa pitkin ja muuttaisi painallukset uudestaan ääniaalloiksi. Crosilla ei ollut taloudellisia mahdollisuuksia rakentaa keksinnöstään mallikappaletta, päinvastoin kuin amerikkalaisella Edisonilla, joka joulukuun lopulla vuonna 1877 haki patenttia fonografinsa prototyypille ja jota yleisesti pidetään mekaanisen äänentallennuksen ja -toiston keksijänä (Gitelman 1999, 63, 72, 98). ${ }^{4}$

Sekä Cros että Edison jatkoivat työtään kahdella rintamalla tai ainakin ääniteknologian ja kirjallisuuden rajamailla. Cros kirjoitti lyriikkaa, jossa yhdistyi kiinnostus äänentoistoon ja menneen rakkaussuhteen äänellisiin merkkeihin, kuten runossa "Inscriptions" 1880-luvulta (julkaistu postuumisti kokoelmassa Le collier de griffes vuonna 1908). Hän myös kirjoitti ironisen novellin koneesta, joka korjaa nalkuttavien naisten ääntä miellyttävämmäksi (vrt. Mikkonen 2001, 28). Patentin saatuaan Edison listasi fonografin mahdollisia käyttötarkoituksia. Fonografi oli aluksi luokiteltu Yhdysvaltain patenttitoimistossa mittalaitteeksi, mutta Edisonin visioissa se saattoi toimia sanelukoneena, saada nuket ja kellot puhumaan - sekä tallentaa romaanit äänen luetussa muodossa (Gitelman 1999, 63). Ensimmäiset fonografilieriöille tallennetut äänikirjat ilmestyivät 1880-luvun lopulla. Niille oli luettu otteita sellaisista populaareista romaaneista kuin Chrales Dickensin Nicholas Nickleby, ja niiden ylistettiin voivan lukea itseään (Gitelman 1999, 64). ${ }^{5}$

Cros ei voinut rakentaa varsinaista tallennuslaitetta, mutta hän tallensi poeettiseen kieleen nostalgisen kaipuunsa menneisyyden ääniä kohtaan. Onnistuttuaan valmistamaan fonografin Edison turvautui kirjallisuuteen laitteen kaupallis-kasvatuksellisia sovelluksia toteuttaessaan. Äänikirjoillaan hän muutti fiktion mykän kielen kuuluvaan muotoon. Äänentoiston ja kirjallisuuden välillä näyttāä siis vallitsevan alun alkujaan yhteys. Kirjallisuuden ja ääniteknologioiden välinen suhde kuitenkin monimutkaistui jälkimmäisen voittokulun myötä. Friedrich A. Kittlerin tulkinnan mukaan kirjallisuuden ja teknologisen median välinen kilpailu 1900-luvun alussa antoi kirjailijoille kaksi vaihtoehtoa. He saattoivat siirtyä voittajan puolelle ja työskennellä filmikäsikirjoittajina tai fonografisävelmien sanoittajina. Toinen mahdollisuus oli hylätä medioiden välinen yhteys ja korostaa kirjallisuutta "kirjainfetisistisesti" sanan taiteena, jota ei puhtaimmillaan voi elokuvata eikä äänittää (koska se ei käänny kuviksi tai koska se on perustavanlaatuisesti äänetöntä). (Kittler 1990/1985, 247-249.) Tilanteeseen on ajateltavissa kolmaskin vaihtoehto. 


\section{Kirjallisuuden ja ääniteknologioiden takaisinkytkentä}

Kittlerin käsitys kirjallisuudesta pelkkänä äänentallennusvälineenä on tietenkin strateginen yksinkertaistus. Se on ymmärrettävä osana hänen yleistä argumenttiaan siitä murroksesta, jonka 1800-luvun lopun mediateknologiat aiheuttivat taiteissa. Maalaustaide ei voinut kilpailla valo- tai elokuvan kanssa optisen tiedon tallentamisen empiirisessä tarkkuudessa yhtään paremmin kuin kirjallisuus fonografisuuden kanssa, kun kyse oli akustisesta datasta. Molemmat teknologiat olivat yli-inhimillisen tarkkoja verrattuna perinteisiin taiteisiin. (Kittler 1990/1985, 245.) Kirjallisuus voidaan kuitenkin mieltää varastoivan tai tallentavan välineen ohella myös synnyttävänä mediumina. Kirjallisuus sekä toistaa että tuottaa akustista dataa, sekä esittää että saa aikaan ääniä (vrt. Schweighauser 2006). Tämä kahtiajako ei tietenkään kata kokonaan äänen tai äänentoistoteknologioiden ja kirjallisuuden dynamiikkaa. Kirjallisuus voi myös hyödyntää lukuisin tavoin - sanastossa, troopeissa tai kerronnan rakenteessa - piirteitä ääniteknologioista, jotka syöksivät sen alun alkujaan vallasta.

Mediateknologiset innovaatiot olivat, mukaillakseni von Clausewitzin sotametaforaa, mimeettisen kielen jatkamista toisin keinoin, mutta niillä oli myös oma vaikutuksensa siihen. Ensinnäkin sellaiset sanonnat kuin "juuttua samaan uraan" tai "nähdä elämän juoksevat filminauhana" olisivat epätodennäköisiä tai ainakin vaikeaselkoisia ilman fonografin tai elokuvan olemassaoloa. Uusien metaforien synnyttämisen lisäksi ääniteknologiset innovaatiot ovat vaikuttaneen 1900-luvun länsimaisen proosan kerrontatekniikkaan. Puhelimessa ja radiossa tapahtunut "luonnollistettu” äänen irtoaminen puhujasta, kielen materiaalisuus fonografisylintereissä tai gramofonikiekoissa sekä diskurssin muutettavuus pois pyyhittävässä, leikattavassa ja uudelleen äänitettävässä ääninauhassa voidaan kaikki yhdistää länsimaisen fiktion rakenteellisiin kokeiluihin, kerronnallisiin ratkaisuihin ja kielikäsityksiin 1870-luvun jälkeen. ${ }^{6}$ Samoin elokuvan äänikäytänteillä (mm. kuvan ulkopuolisella äänellä) sekä leikkaus- ja näkökulmatekniikoilla on yhteytensä moderniin proosaan.

Ääniteknologioiden ja kirjallisuuden välisessä suhteessa on perustavanlaatuinen juopa. Ääni on määritelmänsä mukaisesti kuultavaa mutta näkymätöntä. Silti sitä uskotaan voitavan esittää mykällä mutta näkyvällä kirjoituksella. Patrick O’Donnell ehdottaa tämän paradoksin ratkaisuksi sitä, että vain kielikuvat voivat kirjata ihmisäänen ja että tämä kuvallistaminen vuorostaan korostaa itse kirjoituksen tropologista luonnetta $(1992,7)$. Jättämällä huomiotta muut kuin ihmisäänet O’Donnell onnistuu ratkaisemaan arvoituksen vain osittain. Foneeminen kirjoitus, josta troopit ja koko kirjallinen esitys muodostuvat aakkosten omaksumisen jälkeen, voidaan ymmärtää tallennusvälineeksi, tavaksi vangita ääniä enemmän tai vähemmän pysyvään muotoon. Vastaavasti lukemista voidaan ajatella kirjoitukseen tallennettujen äänten toistamisena, saattamisena kuuluviin. 
Foneettisen kirjoituksen ja äänentallennusvälineen tai lukemisen ja äänentoiston välinen analogia ei ole kuitenkaan täydellinen. Kuten edellä ehdotin, käsitys kirjallisuudesta varastoivana mediumina voidaan kyseenalaistaa vakavasti. Erityisesti Garrett Stewartin "foneemisen lukemisen" teoria esittää, että kirjoitus ja lukeminen eivät yksinkertaisesti toista alkuperäistä äänitapahtumaa, olipa se hypoteettinen tai todellinen. Stewartille foneeminen lukeminen on lukemista kuulevalla silmällä ja näkevällä korvalla. Kyse ei ole ääneen lukemisesta eikä kirjailijan äänen kuulostelusta, vaan sen tunnustamista, että foneettinen kirjoitus ei kykene täysin vangitsemaan kielen äänteellisyyttä ja että vastaanotossa näkö- ja kuuloaisti toimivat yhdessä.

Fonoteksti toistaa enemmän kuin on tallennettu näkyvissä olevan fenotekstin kirjoitukselliseen pintaan. ${ }^{7}$ Tavanomaisessa homofoniassa fonoteksti kaksinkertaistaa kirjoitukseen sisällytetyn informaation (esimerkiksi englannin "holy ja "wholly" tai ranskan "voix" ja "voie" ovat äänteellisesti identtisiä kirjoitusasusta huolimatta). Ilmiö voi tuottaa myös paljon monimutkaisempia artikulaatioita. Esimerkiksi fenotekstuaalinen "impetuous one" Percy Bysshe Shelleyn runossa "Ode to the West Wind" (1820) voidaan lukea foneemisesti muodossa "impet/you/us/one", jolla on myös temaattisesti relevantti, yhteisyyteen ja erillisyyteen liittyvä merkityksensä. (Stewart 1990, 28, 30, 167.)

\section{Kirjoitettu tallenne}

Aivan kuten foneeminen lukeminen toistaa ylimääräisiä merkityksiä kirjoituksesta, fiktiossa representoidut ääniteknologiat paljastavat jotakin muuta kuin itse äänentoistolaitteet ja niiden avulla luodun referentiaalisen illuusion. ${ }^{8}$ Fiktiossa esiintyvät äänen välittämisen, tallentamisen ja toistamisen teknologiat voivat tuoda etualalle tärkeitä kirjallisen kielen ja viestinnän piirteitä. Ei ole sattumaa, että ääni ja kirjoitus näkyvät itse fonografi- ja gramofoni-sanoissa. Edisonin fonografi kaiversi ääniä tinapaperi- tai vahasylintereille ja tuotti merkkejä, jotka muistuttivat kirjoitusta, vaikkakin ihmissilmälle käsittämätöntä ja ikään kuin vieraaseen kirjoitusjärjestelmään kuuluvaa. Fonografinen kirjoitus on mekaanista, kojeen näkyville tuomaa, mutta se on juuri syntytapansa takia paradoksaalisesti "luonnollisempaa" kuin foneettisella kirjoituksella tallennettu puhe. Theodor W. Adornon varhainen kvasifenomenologinen kuvaus gramofonilevystä esseessä ”Die Form der Schallplatte" (1934) sisältää kirjoitusvertauksia ja -metaforia, mutta korostaa samalla äänitysteknisen inskription erityisluonnetta:

musta laatta, joka on tehty sekoitteesta, jolla ei ole enää nykyisin omaa nimeä, yhtä vähän kuin auton polttoainetta kutsutaan bentsiiniksi; se on hauras kuin kirjoitustaulu [Tafel] ja varustettu keskiön pyöreällä etiketillä, joka edelleen näyttää aidoimmalta, kun sitä koristaa isäntänsä ääntä kuunteleva terrieri ajalta ennen sotaa; aivan keskellä pieni reikä, joka on joskus niin ahdas, että sitä koverrettava suuremmaksi, jotta levyn voi asettaa levylautaselle. Levyä peittä- 
vät urat, hennosti raapustettu, täysin lukukelvoton kirjoitus, joka siellä tällä muodostaa plastisempia hahmoja syistä, jotka jäävät kuuntelevalle maallikolle arvoituksiksi; spiraalin muotoisena se päättyy jossakin lähellä etikettiä, johon se joskus yhdistyy loppu-uralla, niin että neula voi mukavasti lopettaa kiertoliikkeensä. (Adorno 1984/1934, 530.)

Fonografinen kirjoitus on, intuition vastaisesti, lukukelvotonta, koska se on indeksikaalista. Tallentaessaan fonografi muuntaa akustisen tapahtuman värähtelyt "välttämättömiksi” ja siten ei-arbitraarisiksi merkeiksi, jotka säilyvät sylinterin pinnalla. Toistaessaan fonografi tuottaa uudelleen äänet, jotka aiheuttivat nuo merkit ja muuntaa lukukelvottoman kirjoituksen takaisin "luonnollisesti” ymmärrettäväksi auditiiviseksi informaatioksi. Tilanne on radikaalisti toinen foneettisen kirjoituksen ja puhutun kielen (tai muiden äänien) välillä. Foneettinen kirjoitus on keinotekoinen ja konventionaalinen. Äänteen ja sitä edustavan merkin välissä suhteessa ei ole mitään "luonnollista" tai välttämätöntä. ${ }^{9}$

Fonografi ja gramofoni ovat analogisia teknologioita, joissa ääni muuntuu tallentavalle pinnalle kaltaisuuden nojalla. Esimerkiksi bassoäänet vaativat enemmän leveyssuuntaista tilaa uralla kuin korkeammat taajuudet, ja tämän eron näkee jo paljaalla silmällä (vaikka tallennetun äänen sisältö jääkin salaisuudeksi). Sitä vastoin digitaaliteknologia tallentaa äänen binaarilukuina, ykkösen ja nollan yhdistelminä. Jos varhaiset analogiset ääniteknologiat olivat indeksikaalisia ja niillä oli välttämätön suhde tallentamaansa materiaaliin, digitaalinen teknologia tavallaan muuntaa akustisen informaation konventionaaliseksi numeeriseksi kirjoitukseksi, binaariaakkosiksi, jotka ovat yhtä keinotekoisia ja sopimuksenvaraisia kuin foneettinen kirjoitus. (Potts 1995.)

Äänentallennusteknologioiden ja kirjoituksen analogia tuo etualalle kysymyksen äänen ja merkinnän välisestä suhteesta. Tämä on erityisen tärkeä ongelma kirjallisuuden kielessä, joka ei vain esitä ääniä, vaan pyrkii usein kuulostamaan esteettisesti sopivalta, joko kauniilta tai rumalta, joko sulavalta tai karkealta. Myös itse väline voi vaikuttaa kirjallisuuden muotoon, muun muassa sen äänimaailmaan.

\section{Topelius ja ensimmäinen fonografi}

Vuoden 1879 helmikuussa Helsingin Ylioppilastalolla esiteltiin Edisonin vain kahta vuotta aikaisemmin patentoima fonografi. Lehti-ilmoitukset kehuivat sen kykenevän "sekä toistamaan kokonaisia lauseita että laulamaan ja soittamaan torvea". (Gronow \& Saunio 1990, 20-21). Keksinnön ihmettelijöiden joukossa oli myös Zacharias Topelius, joka kirjoitti laitteesta runon "Den första fonografen" $(1879)^{10}$ :

Flyende fläkt, luftens fladdrande, gycklande, sladdrande andedräkt! 
Dallrande suck ur naturens lunga,

dig har man gifvit en pratsam tunga.

Utan tanke och utan lif,

vefvar du ord ur ditt positiv.

Käre, håll mund!

Tämj ditt skorrande,

bräkande, morrande

prat en stund!

Än är du ungtupp, som modig galar,

hes i ditt målbrott och tror du talar;

dag skall gry, när med örnaklor

griper du ord, som på tungan bor.

Ekots rival,

ljudets spökande,

härmande, sökande

spegeltal!

Du skall sjunga en framtids visa,

dig skall mången kung Midas prisa ...

Mänskans röst är en världsmusik;

så långt går ej din mekanik.

Runon nimi on yhtä merkillinen kuin profeetallinenkin. Kyse on ilmeisimmin siitä, että laite on ensimmäinen laatuaan, mutta nimi enteilee myös toisten, paranneltujen mallien tulemista. Tilanne on samantapainen kuin jos Topelius olisi kutsunut esittelypaikkaa Vanhaksi ylioppilastaloksi pari vuosikymmentä ennen uuden rakentamista tai jos sarajevolaislehdet olisivat kesällä 1914 uutisoineet ensimmäisen maailmansodan syttyneen.

Runo rakentuu fonografille suunnatusta apostrofista, puhuttelusta. Ensimmäisessä säkeistössä elävä ääni saa tuulenvireeseen ja hengenvetoon liittyviä katoavuuden ja leikkisyyden määreitä. Fonografi taas kuvataan toistavana, posetiivin tavoin elottomasti matkivana laitteena. Toinen säkeistö antropomorfisoi laitteen lörpötteleväksi eukoksi, jota vaaditaan vaikenemaan. Toisaalta fonografin tekniikka vertautuu keskenkasvuisuuteen (ungtupp, målbrott). Viimeinen säkeistö nimeää fonografin luonnonilmiön, kaiun, kilpakumppaniksi ja ennustaa sille kultaista tulevaisuutta, vaikka se ei vedäkään vertoja ihmisäänelle.

Kukin säkeistö on kaksijakoinen suhteessaan fonografiin. Yhtäältä laitteen mullistavuutta tai ainakin sen mahdollista kehittymistä sellaiseksi ylistetään. Toisaalta fonografia halvennetaan (posetiivi, eukko, riittämättömyys; kielteiset ääneen liittyvät attribuutit). Runon jokaisessa säkeistössä toistuu lausekuvio, jonka voisi tulkita imitoivan toimintahäiriöisestä fonografilieriöstä purkautuvaa ääntä. Kolme perättäistä, sidesanatonta adjektiivia tuovat mieleen samaan urankohtaan kiinni jääneen neulan, vaikka itse sanat eivät olekaan identtiset: "fladdrande, gycklande, sladdrande; skorrande, bräkan- 
de, morrande; spökande, härmande, sökande”. ${ }^{11}$ Näin runon muodon voi nähdä olevan mimeettisessä suhteessa kuvaamaansa välineen ominaisuuksiin. Runon kontekstissa ei liene sattumaa, että adjektiivit muodostuvat ande-suffiksilla, jonka homonyymisella substantiivilla on sellaisia merkityksiä kuin 'sielu, henki, henkiolento, haamu'. Tallennehan konkretisoi äänen ruumiista irrallisena entiteettinä. ${ }^{12}$

Runon metaforista monet motivoituvat fonografin tekniikan kautta. Posetiivia ja fonografia yhdistävät kammella tuotettava käyttövoima ja mekaaninen äänentoisto. Sanaan tarttuva haukankynsi vertautuu luontevasti fonografin neulaan, joka vangitsee puheen. Kaiku taas on luonnon esimuoto mekaaniselle äänentoistolle. Ennen fonografin keksimistä ihminen saattoi ainoastaan kaiun avulla kuulla, miltä hänen oma äänensä kuulosti muiden korvissa. ${ }^{13}$

Pekka Gronow ja Ilpo Saunio tulkitsevat leikillisesti, että runon viimeisen säkeistön viittaus kuningas Midakseen ennakoi kultalevyjä (1990, 21). Runon profeetallisuus on kuitenkin olennaisempaa kuin tämä mahdollinen viite äänitetoimialan myöhempiin käytänteisiin. Fonografi ja sittemmin gramofoni eivät menestyneet puheentallennuslaitteena, vaan musiikin toistamisen välineenä, mihin niiden mekaniikka ulottuikin - maailmanlaajuisesti.

\section{Puhelimesta mp3:een}

Kielikuvien tasolla äänen toisto- ja tallennusteknologioiden tavanomaiset piirteet voivat näkyä yksittäisten vertausten tai metaforien lisäksi myös teoksen systemaattisesti hyödynnettynä rakenneperiaatteena. Joskus teknologia suorastaan synnyttää kirjallisuuteen oman alalajinsa, kuten puhelin- tai sähköpostiromaanin tapauksissa.

Puhelin oli ensimmäinen äänenvälitysteknologia, ja se näkyi nopeasti kirjallisuudessakin. Lankapuhelimessa käytävässä keskustelussa on väistämätöntä, että tosiaikainen etäviestintä irrottaa puhujien äänet heidän ruumiistaan. Kommunikaatio tapahtuu pelkän äänen tai oikeastaan sitä välittävän langan varassa. Lanka sekä yhdistää että erottaa puhujat toisistaan, ja samalla se toimii tarinaa yhdistävänä juonensäikeenä. Suomalaisen kirjallisuuden varhaisia puhelinfiktioita ovat mm. seuraavat näytelmät: Ernst Ahlgrenin Telefoonissa (1898), Helena Nyblomin Soitetaan! (1904) ja nimimerkki Evald J:n Langaton telefooni (1907). Ensimmäinen puhelinkertomus Suomessa lienee Maria Jotunin novelli "Hilda Husso" (1913). Edustava esimerkki pelkistä puhelimessa lausutuista repliikeistä koostuvasta romaanista on amerikkalaisen Nicholson Bakerin Vox (1992).

Radio on sekin varhaismuodossaan elävän etäviestinnän väline, tosin yksisuuntainen ja joukoille tarkoitettu. Radiota kirjallisuudessa käytettäessä korostuvat usein läsnäolon illusorisuus, kuten Pentti Haanpään romaanissa Isännät ja isäntien varjot (1935) ja Hannu Raittilan romaanissa Eikä minulta mitään puutu (1998), tai identiteettikysy- 
mykset, kuten Michel Tournierin novellissa "Tristan Vox" (1978).

Levitessään studioista kotikäyttöön 1950-luvulla magnetofoni näkyi kirjallisuudessa varsin kokeellisissa tehtävissä. Ensimmäisenä tulevat mieleen varmastikin Samuel Beckettin Krapp’s Last Tape -näytelmän (1958; Viimeinen ääninauha) elävän ja tallennetun äänen kerrostamat aikatasot sekä William Burroughsin nauhamanipulaatiot romaanissa The Ticket That Exploded (1962). Näitä teoksia kuitenkin edeltää Heinrich Böllin novelli ”Doktor Murkes gesammeltes Schweigen” (1955/1958; ”Tohtori Murken kootut tauot"), joka dramatisoi nauhoitetun kielen materiaalisuuden ja sen altistumisen leikkaamiselle, liittämiselle ja poistolle. Samalla novelli tutkii ideologian vaikutuksia diskurssiin ja yleisemmällä tasolla kielellisen merkityksenmuodostuksen perusteita. Nauhurin digitaalisia mahdollisuuksia hyödyntää mm. Don DeLillon The Body Artist (2001; Esittäjä) ja Hannu Raittilan Pamisoksen purkaus (2005).

Äänilevyä on käytetty aikaisemmin mainitsemieni esimerkkien lisäksi myös päähenkilön tunnetilojen kuvastajana, kuten Thomas Mannin Der Zauberbergin (1928; Taikavuori) viimeisen luvun kuuluisassa jaksossa "Fülle des Wohllauts" ("Sävelaarteita”). Nick Hornbyn High Fidelity (1995; Uskollinen äänentoisto) käyttää lp-, single- ja kasetti-formaatteja systemaattisesti ihmissuhteiden metaforina sekä poimii ääniteknologioista elementtejä retoriikkaansa ja kuvastoonsa.

Miten mp3, uuden vuosituhannen (ääni)teknologia, näkyy kirjallisuudessa? ${ }^{14}$ En muista yhtään esimerkkiä fiktiosta, jossa tähän teknologiaan olisi edes viitattu. Epäilemättä tapauksia, jossa iPod-soitin tai verkosta tiedostojen lataaminen siihen edes mainitaan, on kuitenkin nykykirjallisuudessa viljalti, jo todenkaltaisuuden luomisen takia. Pelkkä referentiaalinen taso ei kenties ole kovin kiintoisa muista kuin talous- tai kulttuurihistoriallisista syistä. Fiktion ulkopuolisessa maailmassa mp3 on tärkeä paitsi musiikin myös äänikirjojen jakelumuoto. On mahdollista, että mp3:a hyödynnetään joskus pelkän jakelun lisäksi myös kirjallisuuden muoto-ominaisuutena. Esimerkiksi satunnaissoitto (shuffle) voisi toimia mallina tekstin rakenneperiaatteelle. Tai vielä geneettisemmin: runoilija saattaisi tallentaa puhumiaan katkelmia soittimeen, käynnistää satunnaistoiminnon ja antaa ohjelman ratkaista tekstin lopullisen järjestyksen. Toisaalta "rippaaminen", eli julkaistujen musiikkitiedostojen irrottaminen kopioimalla alkuperäisestä yhteydestään ja liittäminen soittimen muistiin, voisi toteutua kirjallisuudessa muiden kirjoittamien tekstien sommitteluna uudeksi kokonaisuudeksi. Itse aleatorisuuden tai kollaasin periaatteissa ei ole tietenkään mitään uutta kirjallisuuden historiassa, eikä niiden toteuttamiseen tarvita välttämättä uusinta teknologiaa. Samaa voi sanoa äänen, kirjoituksen ja kirjallisuuden suhteesta. 


\section{Viitteet}

${ }^{1}$ Tämä pitää paikkansa "normaaleissa" mielentiloissa. Skitsofreenikot ja mystikot ovat kautta aikojen väittäneet kuulevansa ääniä, joiden artikuloijat eivät ole läsnä (vrt. Ronell 1989; Stephens \& Graham 2000).

2 Walter J. Ongin terminologiassa "ensisijainen oraalisuus" (primary orality) viitaa kulttuurin tilaan, jossa ei ole mitään käsitystä kirjoituksesta tai kirjapainotekniikasta, kun taas "toissijainen oraalisuus" (secondary orality) merkitsee nykyistä korkean teknologian kulttuuria, jonka joukkotiedotusvälineet pitävät yllä uutta, kirjoitukseen perustuvaa suullisuutta (Ong 1982, 11, 136). Paul Zumthor ehdottaa kolmatta kategoriaa Ongin kahtiajakoon. "Sekoittunut oraalisuus" (oralité mixte) asettuu täysin puhutulle sanalle ja pääasiassa kirjoitukselle perustuvien kulttuurien väliin (Zumthor 1987, 18-19).

${ }^{3}$ Seuraavat esimerkit ovat peräisin Leviniltä (1995), jollei toisin mainita.

${ }^{4}$ Raja teoreettisten ja todellisten keksintöjen välillä on patentin kannalta häilyvä. Teknologia, joka on olemassa vain ideana, ilman sen toimivuuden todistavaa mallikappaletta, voidaan silti patentoida (Gitelman 1999, 110). Tässä mielessä fiktion kuvaukset laitteista, joita ei ole olemassa, eivät poikkea radikaalisti todellisista, patentointia edeltävistä kehittelyistä.

${ }^{5}$ Edison väitti vuoden 1888 parannellun fononografimallin kykenevät mahduttamaan koko Nicholas Nickelby -romaanin neljälle sylinterille. Niiden tallennuskapasiteetti oli kuitenkin vain neljä minuuttia. Nykyaikainen äänikirjaversio tuosta Dickensin romaanista vaatii kaksikymmentäneljä c-kasettia, joiden yhteiskesto on kolmekymmentäkuusi tuntia. (Picker 2003, 114, 185.)

${ }^{6}$ Hiljattain keksittyjä ääniteknologioita käytettiin myös aiheina tai motiiveina 1800-luvun lopun kirjallisuudessa. Esimerkiksi Villiers de l'Isle-Adamin L'Eve future (1886) ja Jules Vernen Le château des Carpathes (1892) hyödynsivät fonografin mahdollisuutta tallentaa ja toistaa ihmisen, erityisesti naisen, ääntä (vrt. Miller Frank 1995, 143-171). Bram Stokerin Dracula (1897) on varsin fonografinen sekä sisällön että kuvaston tasoilla (vrt. esim. Picker 2003, 134-137). Kuten tavallista, runous reagoi maailman muutoksiin, myös teknologisiin innovaatioihin, nopeammin kuin kertova fiktio. Yksi varhaisimmista runoilijoista, joiden säkeissä esiintyy fonografi, on Zacharias Topelius. Palaan hänen "Den första fonografen" runoonsa (1879) esseeni lopulla. Muuan iäkäs englantilaisrunoilija hyödynsi fonografia toisella tavalla. Vuonna 1890 80-vuotias Alfred Tennyson tallensi fonografilla kymmenisen kappaletta omia runojaan (Picker 2003, 125-126). Tuloksena oli yksi varhaisimmista "äänikirjoista”, joilla lukijana toimi kirjailija itse.

${ }^{7}$ 1970-luvun alkupuolella Roland Barthes ja Julia Kristeva alkoivat käyttää sanaparia genoja fenoteksti, joka muodostui mitä ilmeisimmin analogiana biologian geno- ja fenotyypille. Genoteksti viittaa yleisiin semioottisiin operaatioihin, signifikanssiin, kun taas fenoteksti toteuttaa tai ilmentää niitä havaittavassa muodossa. Stewartin fonoteksti rakentuu tuolle kahtiajaolle ja tarkoittaa "sitä artikulaatiovirtaa, jota kirjoituksen loppuminen sananrajoilla ei koskaan mykistä kokonaan”. (Stewart 1990, 27-28.)

${ }^{8}$ Kirjoitettu, eikä välttämättä pelkästään kaunokirjallinen, kieli kantaa tietoa menneiden aikojen äänistä, ja tätä ominaisuutta on hyödynnetty viime vuosikymmeninä monissa tieteenaloissa. Kirjallinen aineisto on ns. äänimaisematutkimuksen tärkein lähde menneisyyden auditiivisuuden selvittelyssä. Esimerkiksi R. Murray Schaferin The Tuning of the World (1977), 
joka aloitti äänimaisematutkimuksen, käyttää korostetusti (kauno)kirjallista materiaalia myös fonografin keksimisen jälkeistä aikaa käsittelevissä jaksoissaan. Schafer oli pääasiassa kiinnostunut luonnon än̈nimaisemista ja siitä, kuinka kulttuuri saastutti ne. Tutkimussuunnan myöhemmissä vaiheissa on siirrytty historiallisempaan ja dynaamisempaan hahmottamiseen määrittelemällä äänimaisema fyysiseksi ympäristöksi ja sen havaitsemisen tavaksi (Thompson 2004, 1); esimerkkejä tällaisista tutkimuksista ovat mm. Corbin (1998/1994) ja Johnson (1995). Kirjallisuustieteellisiä sovelluksia ja kehittelyjä samasta aihepiiristä ovat mm. Bruce R. Smith (1999), Picker (2003) ja Schweighauser (2006). Äänet ovat murtautuneet myös varsinaisen historiantutkimukseen. Historiankirjoitus on perinteisesti ollut - visuaalisten dokumenttien vaikutuksesta - menneistä tapahtumista kertovan mykkäfilmin kaltaista, ennen kuin Mark M. Smithin (2001) tapaiset tutkijat lisäsivät siihen ääniraidan. Myös näennäisen mykästä kuvataiteesta voidaan havaita implisiittisiä ääniä; Pieter Brueghel vanhemman "Karnevaalin ja Paaston taistelu" (1559), Edvard Munchin "Huuto" (1893) ja Pablo Picasson "Guernica" (1937) ovat epäsuorasti melun, musiikin, puheen tai huudahdusten täyttämiä (hälystä Brueghelilla, ks. Attali 1985, 21-24). Myös mykkäelokuvat sisälsivät poikkeuksetta henkilöitä, esineitä tai tapahtumia, joihin liittyi ääntä (vrt. Kahn 2001, 141-142; Lastra 2000, 92-121). Siirtymistä vallitsevasta visuaalisuudesta kohti auditiivisuutta on tapahtunut myös arkkitehtuurin tutkimuksessa, kuten teoksessa Thompson (2004).

${ }^{9}$ Thomas Y. Levin kutsuu fonografista kirjoitusta "samankeskiseksi hieroglyfiksi” (1990, 33), mikä on oikeutettua siinä mielessä, että kummatkaan eivät ole foneettisia eivätkä kokonaan arbitraarisia. Hieroglyfi on jossakin määrin ikoninen, mutta se ei koskaan synny ääniaaltojen vaikutuksesta, päinvastoin kuin ura levyyn.

${ }^{10}$ Runo julkaistiin ensin Helsingfors Morgonbladissa vuonna 1879 ja sittemmin Topeliuksen koottuihin teoksiin sisältyvän Sånger-kokoelman kolmannessa niteessä (1904/1905). Siinä runon alkuperäiseksi ilmestymisvuodeksi ilmoitetaan virheellisesti 1878. Runon digitaalinen faksimile on saatavilla Project Runebergin verkkosivulla (http://runeberg.org/topesang/c0272. html).

${ }^{11}$ Tilanne on siis toinen kuin Paavo Haavikon proosarunossa "Pariisi on vanha kaupunki", jossa paikoilleen juuttuva gramofonineula tuottaa sanatarkkaa toistoa (Haavikko 1977, 32; vrt. Keskinen 2000, 182-185). John M. Pickerin mukaan neulan paikoilleen jääminen esiintyy usein englanninkielisessä modernistisessa kirjallisuudessa, jossa se merkitsee liikkumattomuutta, monotoniaa ja tyhjää toistoa. Sanatarkasti toistettuja lauseita, jotka ovat kuin peräisin rikkinäisestä levystä, esiintyy tässä mielessä mm. Joseph Conradin, T.S. Eliotin, William Faulknerin ja Virginia Woolfin tuotannossa. (Picker 2003, 140.)

${ }^{12}$ Viestintäteknologisten innovaatioiden on usein kuviteltu avaavan väylän yliluonnolliseen, mikä näkyy lennättimen päivistä aina internetiin saakka (vrt. Sconce 2000; Connor 2000, 362-393; Peters 2000, 137-175). Fonografin ja gramofonin suhteesta tuonpuoleiseen ks. Sterne 2003, 287-333.

${ }^{13}$ Oman kuvansa hän pystyi näkemään lukuisissa luonnon heijastavissa pinnoissa, muiden muassa veden kalvossa, ennen kuin peiliä oli olemassa. Douglas Kahnin kiteytyksen mukaisesti "Narkissoksella oli hallussaan parempi teknologia kuin Ekholla" (2001, 8). Fonografin ja kaiun suhteesta ks. myös Kittler 1986, 49-54. Runon ilmaus "spegeltal" yhdistää visuaalisuuden ja auditiivisuuden muodostamalla jonkinlaisen akustisen peilin.

${ }^{14}$ Jonathan Sterne (2006) tarjoaa kiintoisan mediateoreettisen luennan mp3:sta kulttuurisena artefaktina. Samainen tekijä valmistelee aiheesta myös kirjaa. 
Essee perustuu osittain tutkimukseni Audio Book: Essays on Sound Technologies in Narrative Fiction (2008) johdantolukuun.

\section{Lähteet}

Adorno, TheOdor w. 1984/I934: Die Form der Schallplatte. Teoksessa Gesammelten Schriften, osa 19. Toimittaneet Rolf Tiedermann ja Klaus Schultz. Frankfurt am Main: Suhrkamp, 530-534.

attali, JacQues 1985/1977: Noise: The Political Economy of Music. Alkuteos Bruits. Essai sur l'économie de la musique. Kääntänyt Brian Massumi. Minneapolis: University of Minnesota Press.

CONNOR, STEVen 2000: Dumbstruck: A Cultural History of Ventriloquism. Oxford: Oxford University Press.

CORBIN, ALAIN 1998/I994: Village Bells: Sound and Meaning in the 19th-Century French Countryside. Alkuteos Les Cloches de la terre. Paysage sonore et culture sensible dans les campagnes au XIXe siècle. Kääntänyt Martin Thom. New York: Columbia University Press.

CROS, CHARLES 2002: Inscriptions. Collier de griffes. http://abu.cnam.fr/cgi-bin/ go?colliergriffes 1

gitelman, LISA I999: Scripts, Grooves, and Writing Machines: Representing Technology in the Edison Era. Stanford: Stanford University Press.

Gronow, peKka Ja SAUNio, Ilpo I990: Ä̈̈nilevyn historia. Helsinki: WSOY.

haAVIKKo, PaAVO I977: Viiniä, kirjoitusta. Helsinki: Otava.

hrushovski, Benjamin i 980: The Meaning of Sound Patterns in Poetry: An Interaction Theory. Poetics Today, Vol. 2, no.1a, 39-56.

Johnson, JAmes H. I995: Listening in Paris: A Cultural History. Berkeley: University of California Press.

Kahn, DOUglas 200I: Noise, Water, Meat: A History of Sound in the Arts. Cambridge: MIT Press.

KeSKINEN, MIKко 2000: Kuultava kirjoitus: ääni ja puhe kirjallisuudessa. Teoksessa Kirjallisuus, kieli ja kognitio: kognitiivisesta kirjallisuuden- ja kielentutkimuksesta. Toimittaneet Katriina Kajannes ja Leena Kirstinä. Helsinki: Helsinki University Press, 159-193.

KeSkinen, MiкKо 2008: Audio Book: Essays on Sound Technologies in Narrative Fiction. Lanham: Lexington Books. (Painossa.)

KITTLER, FRIEDRICH A. I986: Grammophon - Film - Typewriter. Berlin: Brinkmann \& 
Bose.

KITTLER, FRIEDRICH A. I990/I 98 5: Discourse Networks 1800/1900. Alkuteos Aufschreibsysteme 1800/1900. Kääntäneet Michael Metteer ja Chris Cullens. Stanford: Stanford University Press.

Lastra, James 2000: Sound Technology and the American Cinema: Perception, Representation, Modernity. New York: Columbia University Press.

LEVIN, Thomas y. I990: For the Record: Adorno on Music in the Age of Its Technical Reproducibility. October 55, 33.

LEVIN, THOMAS Y. I995: Before the Beep: A Short History of Voice Mail. Teoksessa Essays in Sound 2: Technophonia. Toimittanet Alessio Cavarallo, Shaund Davies, Frances Dyson ja Annemarie Jonson. http://www.sysx.org/soundsite/csa/eis2content/essays/ p59_beep.html

mikkonen, Kai 200I: The Plot Machine: The French Novel and the Bachelor Machines in the Electric Years (1880-1914). Amsterdam \& New York: Rodopi.

Miller frank, Felicia i 995: The Mechanical Song: Women, Voice, and the Artificial in Nineteenth-Century French Narrative. Stanford: Stanford University Press.

o'donnell, PATRICK I992: Echo Chambers: Figuring Voice in Modern Narrative. Iowa City: University of Iowa Press.

ONG, WALter J. I982: Orality and Literacy: Technologizing of the Word. London: Methuen.

PETERS, JOHN DURHAM 2000: Speaking into the Air: A History of the Idea of Communication. Chicago: University of Chicago Press.

PICKeR, JOHn M. 2003: Victorian Soundscapes. Oxford: Oxford University Press.

роттS, JOHN 1995: Schizochronia: Time in Digital Sound. Teoksessa Essays in Sound 2:

Technophonia. Toimittaneet Alessio Cavarallo, Shaund Davies, Frances Dyson ja Annemarie Jonson. http ://www.sysx.org/soundsite/csa/eis2content/essays/p17_skiz.html ronell, avital 1989: The Telephobe Book: Technology, Schizophrenia, Electric Speech. Lincoln: University of Nebraska Press.

SCHAFER, R. MURRAY I994: The Soundscape: Our Sonic Environment and the Tuning of the World. (Saman tekijän The Tuning of the World-teoksen [1977] uusintapainos.) Rochester: Destiny.

SCHWeighaUSER, Philipp 2006: The Noises of American Literature, 1890-1985: Toward a History of Literary Acoustics. Gainsville: University Press of Florida.

SMith, BRUCE R. I999: The Acoustic World of Early Modern England: Attending to the OFactor.Chicago: University of Chicago Press.

SMith, MARK M. 200 I: Listening to Nineteenth-Century America. Chapel Hill: University of North Carolina Press.

sCONCE, JefFrey 2000: Haunted Media: Electronic Presence from Telegraphy to Television. Durham: Duke University Press. 
STEPhens, G. LYNN \& GRAHAM, GeORGe 2000: When Self-Consciousness Breaks: Alien Voices and Inserted Thoughts. Cambridge: MIT Press.

Sterne, jonathan 2003: The Audible Past: Cultural Origins of Sound Reproduction. Durham: Duke University Press.

sterne, jonathan 2006: The Mp3 as Cultural Artifact. New Media \& Society, Vol. 8, no. $5,825-842$.

STEWART, GARRETT I990: Reading Voices: Literature and the Phonotext. Berkeley: University of California Press.

THOMpson, EMILY 2004: The Soundscape of Modernity: Architectural Acoustics and the Culture of Listening in America, 1900-1933. Cambridge: MIT Press.

topelius, zacharias: Den första fonografen. Sånger, osa III. Project Runeberg. http:// runeberg.org/topesang/c0272.html

zumthor, paul 1987: La lettre et la voix. De la "ittérature" médiévale. Paris: Seuil. 